\title{
TITLE:
}

\section{MATTER SYSTEM IRRADIATED BY COHERENT LIGHT(Abstract_要旨)}

AUTHOR(S):

Mabuchi, Mahito

\section{CITATION:}

Mabuchi, Mahito. MATTER SYSTEM IRRADIATED BY COHERENT LIGHT. 京都大学, 1977, 工学博士

ISSUE DATE:

1977-09-24

URL:

http://hdl.handle.net/2433/221550

RIGHT: 


\section{【231 】}

\begin{tabular}{|c|c|}
\hline 名 & $\begin{array}{l}\text { 真 } \\
\text { ま }\end{array}$ \\
\hline 学 位の種 類 & 工 \\
\hline 学位記番号 & 工 博 第 523 号 \\
\hline 学位授与の日付 & 昭 和 52 年 9 月 24 日 \\
\hline 学位授与の要件 & 学 位 規 則 第 5 条第 1 項該 当 \\
\hline 开究科・専攻 & 工学研究科原子核工学専攻 \\
\hline 学位論文題目 & $\begin{array}{l}\text { MATTER SYSTEM IRRADIATED BY COHERENT } \\
\text { LIGHT }\end{array}$ \\
\hline
\end{tabular}

(レーザー光に照射された物質系)

論文調查委員教主菣 向坂正勝 教授片山泰久教授西原宏

\section{論交内容の要旨}

この論文は，レーザー光に照射された物質系，すなわち光子・原子系における非線型双極子励起状態 を研究し，光子及び原子の位相特性をむ解明することを目的とし， 5 章から成っている。

第 1 章は序論で, 研究の目的及び主題が示されている。

第 2 章では, 高密度フレンケル型励起子を記述する新しいハミルトニアンを， 2 準位原子モデルの枠 組の中で導いた。とのハミルトニアンは，原子間に電子の波動関数の重なりがない単一成分原子系にお

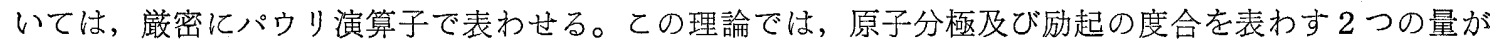
基本量となる。とのハミルトニアンは, 低密度励起子の極限では, 従来の低密度フレンケル励起子の八 ミルトニアンに一致するが, 高密度の場合には, 上記の励起の度合を表わす量の存在のため, 励起子は 非線型挙動を示す。との意味で，フレンケル型励起子は一般に非線型分極波と見なすと文ができる。

第 3 章では, フレンケル型励起子が多数集まって作る孤立波の存在が導かれている。フレンケル型励 起子間相互作用は, 励起子間距離の 5 乗に逆比例する。フレンケル型励起子の状態を水素原子の波動関 数で近似すると，ての相互作用は $1.4 \mathrm{meV}$ の弱い反発之評価される。

励起子間相互作用のない低密度励起子は，従来から知られているように平面波的に振舞うが，上記の相 互作用の屯とでは，低密度の場合，横波が孤立波を作り易い。との章の結論は，一般に，ボーズ粒子系 では近距離相互作用のもとに孤立波の存在が可能である，というととである。

第 4 章では, レーザー光すなわち強い可干渉光に物質が照射されたときに生じる，光と物質の結合系 における 2 成分コヒーレント状態が取り扱われている。との 2 成分コヒーレント状態は, 光と物質の相 互作用を他の項にくり込むユニタリ一变換から導かれる。このコヒーレント状態は，物質系の大きさ， 光・原子間結合定数, 光の振動数, 及び原子双極子の配列に依存する。この状態では, 光と物質の相互 作用エネルギーは，物質系と光子系の位相が一致するとき，最小となる。これは位相の保存則であって， 多体的効果による。一方では, 光子の吸収率は, 両系の位相差が大きい程, 大きくなる。これは一種の 
ジョセフソン効果と見なされる。また，入射光の位相と物質系の位相に注目するととによって，散乱及 び発光の過程をそれぞれ, 入射光の位相と放出される光の位相が相関をむつ場合, 及び両者が相関を持 たない場合として理解し得る。

第 5 章は結言である。

\section{論交審查の結果の要旨}

最近におけるレーザー技術の進歩に伴って, 強い可干涉光を物質にあて, 密度の高い双極子励起状態 をつくり出し得るようになり，種々の興味ある現象が発見されている。本論文は，可干渉性の強い光之 物質との相互作用の基礎理論を，2準位原子結晶中のフレンケル励起子モデルの枠組の中で展開したも ので，得られた主な成果はつぎの通りである。

（1）結晶中に生じる高密度フレンケル型励起子に対するハミルトニアンを導いた。とのハミルトニア ンは，原子間に電子の波動関数の重なりのない 2 準位原子系では，パウリ演算子によって綮密に記述さ れ，一般に従来のボーズ演算子表示より正確であり，また低密度励起子の極限で従来の表式に一致する。

（2）乙の新しいハミルトニアンに含まれるパウリ演算子をボーズ演算子に展開することにより，この ハミルトニアンが従来のハミルトニアンに含まれる励起子間相互作用より多くの非線型相互作用を含み 従って一層広い範囲に適用できることが示された。

（3）とのようにボーズ演算子に展開したハミルトニアンを用いて，低密度励起子の集団運動において 孤立波の生じうるととを示し，さらに一般に，最近接相互作用をうけるボーズ粒子系において孤立波の 存在し得ることを証明した。

(4) 上記(1)で導いたハミルトニアンに抢いて電磁場を量子化し, さらに自由電場の項を加えて, 光子 ・原子結合系のハミルトニアンを導き，励起子間相互作用を省略し光子・原子間相互作用をユニタリー 変換で他の項にくり込むととによって，2 成分系のコヒーレントな状態を定式化した。との状態は, 強 い可干渉光の入射によって物質中に光と同位相の励起子集団が生じたものであって，物質の大きさ， 光・原子間結合定数，光の振動数及び原子双極子の配列に依存するととなどが示された。

（5）励起子集団の統計的振舞を調べ, 分極能を秩序パラメーターとする第 2 種相軽移が, 従来から知 られているボーズ凝縮とは違った意味で起りうるととを示した。

以上述べたように，との論文は，2準位原子モデルを用いてフレンケル励起子の理論を展開し, 励起 子間の直接相互作用による孤立波，すなわちパルス状励起子集団の形成されることを示し，さらに，強 い可干涉光に照射された物質中における光子・原子系のコヒーレントな状態と相転移の理論を導出した もので，学術上寄与するところがすくなくない。

よって，本論文は工学博士の学位論文として価值あるものと認める。 